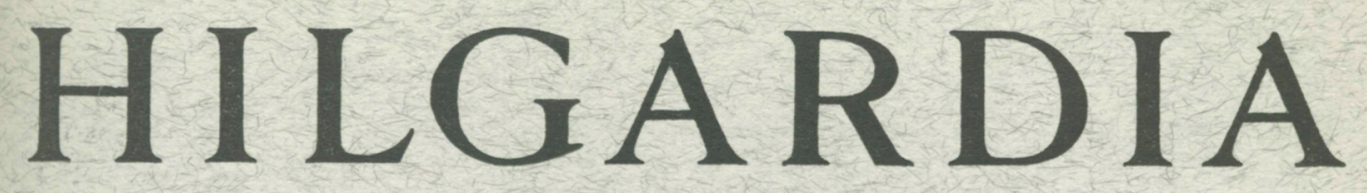

A Journal of Agricultural Science Published by the California Agricultural Experiment Station

\title{
CATION-EXCHANGE PROPERTIES OF SOME ACID SOILS OF CALIFORNIA
}

\author{
P. F. PRATT and F. L. BAIR
}

UNIVERSITY OF CALIFORNIA - BERKELEY, CALIFORNIA 


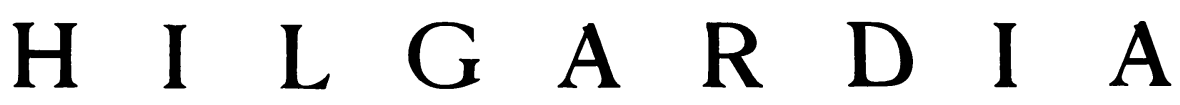

A Journal of Agricultural Science Published by

the California Agricultural Experiment Station

\section{CATION-EXCHANGE PROPERTIES OF SOME ACID SOILS OF CALIFORNIA ${ }^{1}$}

\section{P. F. PRATT ${ }^{2}$ and F. L. BAIR ${ }^{3}$}

MosT soll acidification experiments are conducted in laboratory or greenhouse over short periods of time, and there is always some uncertainty concerning the application of the data to the field where soils are acidified over a much longer period. Thus, the data presented in this report, part of a study of acid soil samples from the field, provide a background against which to compare the results of short-term experiments.

This report is not intended to be a complete survey of acid soils of California because too few samples have been included. But there are a sufficient number to provide a wide range in such properties as clay and organic $\mathrm{C}$ content, cation-exchange capacity (CEC), clay mineral content and $\mathrm{pH}$. The samples also represent a variety of acid soils found in central and southern California. Cole (1949) 4 reported the acidity and alkalinity of soils of California that had been previously surveyed.

\section{SOIL SAMPLES}

Data on county location, $\mathrm{pH}$, clay and organic $\mathrm{C}$ contents of 31 samples are presented in table 1 . The clay content was measured by a pipette method and the organic C by a modified Walkley-Black method (Pratt et al. 1957). With the exception of samples 27,29 and 31, all were taken from the surface soil of cultivated fields or from the $A_{1}$ horizon of undisturbed soils. Samples 27,29 and 31 were taken from the horizon immediately below the plow layer of the same soils as samples 26,28 and 30 , respectively. All samples were airdried and then ground to pass a $2 \mathrm{~mm}$ screen. Subsamples ground to pass a 60-mesh sereen were used where small portions were taken for analysis. Sixteen of the samples were taken from central California and fifteen came from Kern and San Diego counties.

Data on the relative abundance of various minerals in the clay fractions of a number of soils are presented in table 2. The clay in twelve of these samples was dominantly illite and montmorillonite, and in seven samples there were mixtures, with montmorillonite constituting only a small portion.

${ }^{1}$ Submitted for publication March, 1962.

${ }^{2}$ Associate Professor of Soil Sciences and Associate Chemist in the Experiment Station, Riverside.

${ }^{3}$ Laboratory Technician, Department of Soils and Plant Nutrition, Riverside.

"See "Literature Cited" for citations referred to in the text by author and date. 
Data on percentage of water at saturation, and soluble cations in the saturation extract are presented in table 3 . Fifteen of the samples contained more than 40 meq total cations per liter and of these fifteen, eight contained more than 80 meq per liter. Thus, about half of the samples can be classified as of medium to high salinity. All of these were from irrigated fields, with the ex-

TABLE 1

COUNTY LOCATION, pH, CLAY AND ORGANIC C CONTENTS OF SOIL SAMPLES

\begin{tabular}{|c|c|c|c|c|}
\hline Soil No. & Location & $\mathrm{pH}^{*}$ & Clay & Organic $\mathrm{C}$ \\
\hline & County & & Per cent & Per cent \\
\hline 1. & San $D_{1}$ & 5.8 & 8.9 & 0.5 \\
\hline 2. & 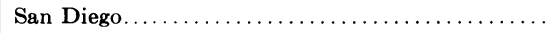 & 6.0 & 5.6 & 0.4 \\
\hline 3. & 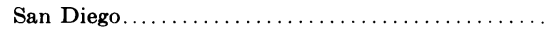 & 4.0 & 10.9 & 0.7 \\
\hline 4. & 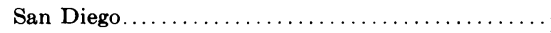 & 6.0 & 5.3 & 1.4 \\
\hline 5. & 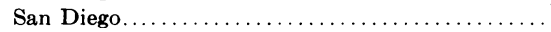 & 5.0 & 4.6 & 0.4 \\
\hline 6. & 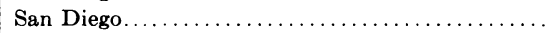 & 6.3 & 32.3 & 1.4 \\
\hline 7. & 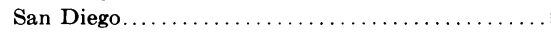 & 5.2 & 4.8 & 0.5 \\
\hline 8. & 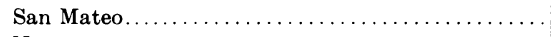 & 4.4 & 8.9 & 0.8 \\
\hline 9. & 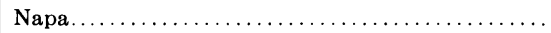 & 3.6 & 43.2 & 3.4 \\
\hline 10. & 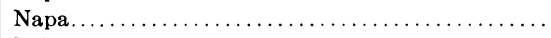 & 4.1 & 49.3 & 3.7 \\
\hline 11. & 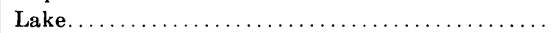 & 5.7 & 41.8 & 3.4 \\
\hline 12. & 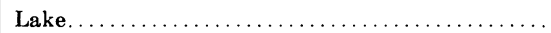 & 5.6 & 28.3 & 3.2 \\
\hline 13. & 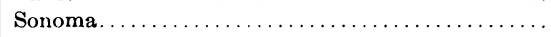 & 5.7 & 53.0 & 2.2 \\
\hline 14. &  & 5.8 & 51.2 & 1.8 \\
\hline 15. & 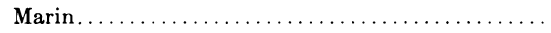 & 5.4 & 18.3 & 2.6 \\
\hline 16. & 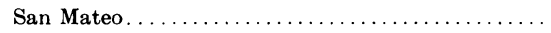 & 4.5 & 12.1 & 1.6 \\
\hline 17. & 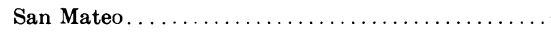 & 5.4 & 15.6 & 1.9 \\
\hline 18. & 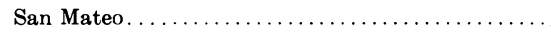 & 5.4 & 17.0 & 2.1 \\
\hline 19. & 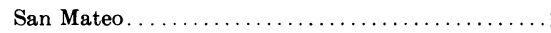 & 4.7 & 18.9 & 2.0 \\
\hline 20. & 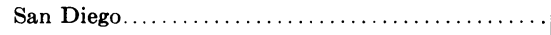 & 7.0 & 11.3 & 0.8 \\
\hline 21. &  & 5.2 & 7.8 & 0.3 \\
\hline 22. & $\ldots \ldots \ldots \ldots \ldots \ldots \ldots \ldots \ldots$ & 6.4 & 9.5 & 0.2 \\
\hline 23. & 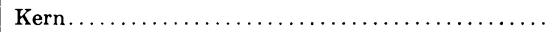 & 4.9 & 10.6 & 0.4 \\
\hline 24. & Kern $\ldots \ldots \ldots \ldots \ldots \ldots \ldots \ldots \ldots \ldots \ldots \ldots$ & 5.3 & 10.2 & 0.2 \\
\hline 25. & 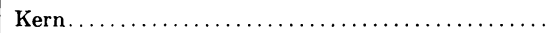 & 5.1 & 62.0 & 3.5 \\
\hline 26. & 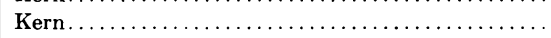 & 4.7 & 64.5 & 3.7 \\
\hline 27. & 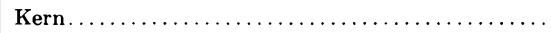 & 4.0 & 56.7 & 2.8 \\
\hline 28. & 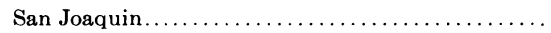 & 5.8 & 47.3 & 14.8 \\
\hline 29. &  & 5.6 & 45.1 & 15.1 \\
\hline 30. & 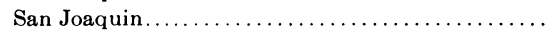 & 5.2 & 25.4 & 9.5 \\
\hline 31. & 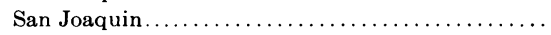 & 5.2 & 21.4 & 0.4 \\
\hline
\end{tabular}

* At 1-1 dilution with water.

ception of numbers 9 and 10 taken from areas in Napa County which were influenced by salt water intrusion from San Pablo Bay. All other samples, collected from nonirrigated areas, were of low salinity. The data illustrate the fact that, although most acid soils are nonsaline, those that are irrigated can become highly saline.

Values of $0.5 \mathrm{ppm} \mathrm{Al}$ and $10 \mathrm{ppm} \mathrm{Mn}$ were used as diagnostic criterion for $\mathrm{Al}$ and $\mathrm{Mn}$ toxicity for sensitive plants; six soils were found to have toxic Al concentrations and thirteen soils toxic Mn concentrations. Compared with acid soils of the humid regions of eastern USA, having $\mathrm{pH}$ values of between 4 and 5 , the soluble $\mathrm{Al}$ values presented in table 2 are relatively low. For example, Pierre et al. (1932) found 1.0 to $27.2 \mathrm{ppm} \mathrm{Al}$ in the soil solution of soils having $\mathrm{pH}$ values near 4.5, Magistad (1925) found 16 to 
$96 \mathrm{ppm} \mathrm{Al}$ in soil solutions for soils having $\mathrm{pH}$ values of 4.0 to 4.5, and Schmehl et al. (1950) found that a Mardin silt loam with $\mathrm{pH} 4.75$ had 1.9 $\mathrm{ppm} \mathrm{Al}$ in the displaced solution of the untreated soil and $10 \mathrm{ppm} \mathrm{Al}$ when gypsum was added.

TABLE 2

RELATIVE ABUNDANCE OF CLAY MINERALS FOUND IN THE CLAY FRACTIONS OF A NUMBER OF ACID SOILS

\begin{tabular}{|c|c|c|c|c|c|c|c|c|c|c|}
\hline \multirow{2}{*}{ Sample No. } & \multirow{2}{*}{$\begin{array}{l}\text { Effective } \\
\text { size } \\
\text { fraction }\end{array}$} & \multirow{2}{*}{$\begin{array}{l}\text { Per cent } \\
\text { of total } \\
\text { clay }\end{array}$} & \multicolumn{8}{|c|}{ Mineral composition } \\
\hline & & & Mi & $\mathrm{Vm}$ & $\mathrm{Mt}$ & $\mathrm{Chl}$ & $\mathrm{Kl}$ & Qt & $\mathrm{Fl}$ & Am \\
\hline & Microns & & & & & & & & & \\
\hline \multirow[t]{2}{*}{$3 \ldots \ldots \ldots \ldots$} & $2.0-0.2$ & 48 & $\mathrm{xx}$ & .. & $\mathrm{xx}$ & .. & $\mathrm{XX}$ & $\mathrm{XX}$ & $\mathrm{x}$ & .. \\
\hline & $<0.2$ & 52 & $\mathrm{X}$ & .. & XXX & .. & $\mathrm{X}$ & $\mathrm{X}$ & .. & .. \\
\hline \multirow{2}{*}{$5 \ldots \ldots \ldots \ldots$} & $2.0-0.2$ & 57 & $\mathrm{xx}$ & .. & $\mathrm{xx}$ & .. & $\mathrm{XX}$ & $\mathrm{XX}$ & $\mathrm{X}$ & .. \\
\hline & $<0.2$ & 43 & $\mathbf{X}$ & .. & $\mathrm{XXX}$ & .. & $\mathrm{X}$ & $\mathrm{x}$ & .. & .. \\
\hline \multirow[t]{2}{*}{$6 \ldots \ldots \ldots \ldots$} & $2.0-0.2$ & 29 & $\mathrm{XXX}$ & .. & $\mathrm{X}$ & .. & $\mathrm{X}$ & $\mathrm{XXX}$ & $\mathrm{x}$ & .. \\
\hline & $<0.2$ & 71 & $\mathrm{XX}$ & .. & XXX & .. & $\mathrm{X}$ & & .. & .. \\
\hline \multirow{2}{*}{$8 \ldots \ldots \ldots \ldots$} & $2.0-0.2$ & 79 & $\mathrm{X}^{*}$ & .. & .. & $\mathrm{X}^{*}$ & $\mathrm{x}$ & $\mathrm{XXX}$ & $\mathrm{X}$ & \\
\hline & $<0.2$ & 21 & .. & .. &. & .. & .. & .. & .. & $\mathrm{XXX}$ \\
\hline \multirow[t]{2}{*}{$9 \ldots \ldots \ldots \ldots$} & $2.0-0.2$ & 51 & $\mathrm{X}$ & .. & $\mathrm{XXX}$ & $\mathrm{X}$ & $\mathrm{XX}$ & $\mathrm{XX}$ & $\mathrm{x}$ & .. \\
\hline & $<0.2$ & 49 & $\mathrm{X}$ & .. & $\mathrm{XXX}$ & .. & $\mathrm{X}$ & $\mathrm{X}$ & .. & .. \\
\hline \multirow[t]{2}{*}{$10 \ldots \ldots \ldots \ldots \ldots$} & $2.0-0.2$ & 53 & $\mathrm{x}$ & .. & $\mathrm{XXX}^{*}$ & $\mathrm{X}^{*}$ & $\mathrm{x}$ & $\mathrm{XX}$ & $\mathrm{x}$ & .. \\
\hline & $<0.2$ & 47 & .. &.. & $\mathrm{XXXX}$ & .. & .. & $\mathrm{X}$ & .. & .. \\
\hline \multirow[t]{2}{*}{$11 \ldots \ldots \ldots \ldots$} & $2.0-0.2$ & 57 & .. & .. & .. & .. & $\mathrm{X}$ & .. & .. & XXXX \\
\hline & $<0.2$ & 43 & .. & .. & .. & .. & $\mathrm{X}$ & .. & .. & XXXX \\
\hline \multirow[t]{2}{*}{$12 \ldots \ldots \ldots \ldots \ldots$} & $2.0-0.2$ & 67 & .. & .. & .. & $\mathrm{X}$ & $\mathrm{X}$ & $\mathrm{X}$ & .. & XXX \\
\hline & $<0.2$ & 33 & .. & .. & & & $\mathbf{x}$ & & .. & $\mathrm{XXX}$ \\
\hline \multirow{2}{*}{$14 \ldots \ldots \ldots \ldots$} & $2.0-0.2$ & 46 & $\mathbf{X}$ & .. & $\mathrm{XXX}^{*}$ & $\mathrm{X}^{*}$ & $\mathrm{XX}$ & $\mathrm{x}$ & $\mathrm{X}$ & .. \\
\hline & $<0.2$ & 54 & $\mathrm{X}$ & .. & $\mathrm{XXX}$ & & $\mathbf{X}$ & $\mathrm{x}$ & .. & .. \\
\hline \multirow[t]{2}{*}{$15 \ldots \ldots \ldots \ldots$} & $2.0-0.2$ & 46 & $\mathrm{X}$ & $\mathrm{XX}$ &.. & $\mathrm{X}$ & $\mathrm{X}$ & $\mathrm{xx}$ & $\mathrm{x}$ & .. \\
\hline & $<0.2$ & 54 & .. & $\mathrm{XX}$ & $\mathbf{X}$ & .. & .. & .. & .. & .. \\
\hline \multirow[t]{2}{*}{$16 \ldots \ldots \ldots \ldots \ldots$} & $2.0-0.2$ & 57 & $\mathrm{X}$ & $\mathrm{x}$ & .. & .. & $\mathrm{x}$ & $\mathrm{XX}$ & $\mathrm{X}$ & $\mathrm{x}$ \\
\hline & $<0.2$ & 43 & .. & .. & .. & .. & $\mathrm{XX}$ & .. & .. & $\mathrm{X}$ \\
\hline \multirow[t]{2}{*}{$17 \ldots \ldots \ldots \ldots$} & $2.0-0.2$ & 43 & $\mathrm{X}$ & $\mathrm{X}$ & .. & .. & .. & .. & .. & .. \\
\hline & $<0.2$ & 57 & $\cdots$ & .. & $\mathrm{X}$ & .. & .. & & .. & .. \\
\hline \multirow{2}{*}{$18 \ldots \ldots \ldots \ldots$} & $2.0-0.2$ & 37 & $\mathrm{XX}$ & .. & .. & .. & $\mathrm{X}$ & XXX & $\mathrm{X}$ & .. \\
\hline & $<0.2$ & 63 & .. & .. & & .. & $\mathrm{XX}$ & & .. & $\mathrm{x}$ \\
\hline \multirow{2}{*}{$22 \ldots \ldots \ldots \ldots$} & $2.0-0.2$ & 57 & $\mathrm{XXX}$ & .. & $\mathrm{XXX}$ & .. & $\mathbf{x}$ & $\mathrm{X}$ & $\mathrm{x}$ & .. \\
\hline & $<0.2$ & 43 & & .. & $\mathrm{XXX}$ & .. & $\mathbf{x}$ & $\mathrm{X}$ & .. & .. \\
\hline \multirow[t]{2}{*}{$23 \ldots \ldots \ldots \ldots \ldots$} & $2.0-0.2$ & 64 & $\mathrm{XXX}$ & .. & $\mathrm{XX}$ & .. & $\mathrm{X}$ & $\mathrm{X}$ & .. & .. \\
\hline & $<0.2$ & 36 & $\mathrm{X}$ & .. & $\mathrm{XXX}$ & .. & .. & $\mathrm{X}$ & .. & .. \\
\hline \multirow[t]{2}{*}{25.} & $2.0-0.2$ & 47 & $\mathrm{x}$ & .. & $\mathrm{XXXX}$ & .. & $\mathrm{X}$ & $\mathrm{X}$ & $\mathrm{X}$ & .. \\
\hline & $<0.2$ & 53 & $\mathrm{x}$ & .. & $\mathrm{XXXX}$ & .. & $\mathrm{x}$ & $\mathrm{X}$ & .. & .. \\
\hline \multirow[t]{2}{*}{$28 \ldots \ldots \ldots \ldots \ldots$} & $2.0-0.2$ & 61 & $\mathrm{X}$ & .. & XXX & .. & $\mathrm{XX}$ & $\mathrm{X}$ & $\mathrm{x}$ & .. \\
\hline & $<0.2$ & 39 & .. & .. & $\mathrm{XX}$ & .. & $\mathrm{X}$ & $\cdots$ & .. & $\mathrm{x}$ \\
\hline \multirow[t]{2}{*}{$29 \ldots \ldots \ldots \ldots \ldots$} & $2.0-0.2$ & 62 & .. & .. & XXX & .. & $\mathrm{X}$ & $\mathrm{X}$ & .. & .. \\
\hline & $<0.2$ & 38 & $\mathrm{X}$ & .. & $\mathrm{xx}$ & .. & $\mathrm{x}$ & .. & .. & .. \\
\hline \multirow[t]{2}{*}{$30 \ldots \ldots \ldots \ldots \ldots$} & $2.0-0.2$ & 59 & $\mathrm{x}$ & .. & $\mathrm{XXXX}$ & .. & $\mathrm{XX}$ & $\mathrm{X}$ & $\mathrm{X}$ & .. \\
\hline & $<0.2$ & 41 & .. & .. & $\mathrm{XXX}$ & .. & .. & .. & .. & .. \\
\hline * Interstra & $\begin{array}{l}\mathrm{Mi}= \\
\mathrm{Vm}= \\
\mathrm{Mt}= \\
\mathrm{Chl}= \\
\mathrm{Kl}= \\
\mathrm{Qt}= \\
\mathrm{Fl}= \\
\mathrm{Am}=\end{array}$ & $\begin{array}{l}=\text { mica (illi } \\
=\text { vermicul } \\
=\text { montmor } \\
=\text { chlorite } \\
=\text { kaolinite } \\
=\text { quartz } \\
=\text { feldspar } \\
=\text { amorpho }\end{array}$ & lonite & & & & $\begin{array}{r}= \\
x=\end{array}$ & $\begin{array}{l}\text { tectable } \\
\text { derate } \\
\text { undant } \\
\text { edomin }\end{array}$ & & \\
\hline
\end{tabular}




\section{EXCHANGEABLE CATIONS}

Data on exchangeable cations, including exchange acidity extracted by unbuffered $N \mathrm{KCl}$ and by buffered ( $\mathrm{pH} 8.2$ ) $\mathrm{BaCl}_{2}$-triethanolamine (TEA) following the $\mathrm{KCl}$ extraction, as well as $\mathrm{CEC}$ are presented in table 4 . The exchangeable $\mathrm{Ca}, \mathrm{Mg}, \mathrm{Na}$ and $\mathrm{K}$ represent the amounts extracted by neutral

TABLE 3

WATER CONTENT AT SATURATION AND CATIONIC CONCENTRATIONS OF SATURATION EXTRACT OF SOILS

\begin{tabular}{|c|c|c|c|c|c|c|c|c|c|c|}
\hline \multirow{2}{*}{$\begin{array}{l}\text { Soil } \\
\text { No. }\end{array}$} & \multirow{2}{*}{$\begin{array}{c}\begin{array}{c}\text { Water } \\
\text { content }\end{array} \\
\text { Per cent }\end{array}$} & $\mathrm{Ca}$ & $\mathbf{M g}$ & $\mathrm{Na}$ & $\mathbf{K}$ & \multicolumn{2}{|c|}{$\mathrm{Al}$} & \multicolumn{2}{|c|}{ Mn } & \multirow{2}{*}{$\begin{array}{c}\begin{array}{c}\text { Total } \\
\text { cations }\end{array} \\
m e q / l\end{array}$} \\
\hline & & \multicolumn{4}{|c|}{$m e q / l$} & $m e q / l$ & ppm & $m e q / l$ & ppm & \\
\hline 1 & 24 & 12.8 & 9.7 & 14.7 & 0.4 & $\mathrm{ND}^{*}$ & ND & 0.38 & 10.8 & 38.0 \\
\hline 2 & 22 & 9.6 & 4.4 & 3.9 & 2.6 & ND & ND & 0.19 & 5.2 & 20.7 \\
\hline 3 & 28 & 55.0 & 31.4 & 31.1 & 12.8 & 0.56 & 5.0 & 5.7 & 158.0 & 136.6 \\
\hline 4 & 21 & 3.3 & 1.8 & 3.2 & 1.9 & ND & ND & 0.14 & 3.8 & 10.3 \\
\hline 5 & 22 & 34.7 & 27.8 & 34.2 & 3.4 & 0.02 & 0.2 & 1.7 & 46.4 & 101.8 \\
\hline 6 & 47 & 0.9 & 0.8 & 6.3 & 0.3 & ND & ND & ND & ND & 8.3 \\
\hline 7 & 26 & 27.3 & 8.6 & 7.8 & 5.6 & 0.01 & 0.1 & 2.0 & 55.2 & 51.3 \\
\hline 8 & 25 & 6.0 & 2.8 & 2.2 & 1.9 & 0.08 & 0.7 & 0.63 & 17.2 & 13.6 \\
\hline 9 & 72 & 16.9 & 46.4 & 51.2 & 2.0 & 12.0 & 108.0 & 1.2 & 33.8 & 129.7 \\
\hline 10 & 70 & 10.0 & 29.4 & 88.8 & 1.2 & 0.36 & 3.2 & 0.60 & 16.6 & 130.4 \\
\hline 11 & 81 & 1.6 & 1.5 & 1.5 & 0.1 & ND & ND & ND & ND & 4.7 \\
\hline 12 & 44 & 1.8 & 0.6 & 0.6 & 0.7 & ND & ND & 0.09 & 2.6 & 3.8 \\
\hline 13 & 61 & 0.4 & 1.0 & 2.1 & 0.4 & ND & ND & ND & ND & 3.9 \\
\hline 14 & 58 & 0.5 & 1.0 & 1.0 & 0.3 & ND & ND & ND & ND & 2.8 \\
\hline 15 & 34 & 1.8 & 1.6 & 1.9 & 0.1 & 0.01 & 0.1 & ND & ND & 5.4 \\
\hline 16 & 29 & 37.7 & 24.7 & 12.1 & 7.9 & 0.1 & 0.9 & 0.87 & 24.0 & 83.4 \\
\hline 17 & 37 & 0.5 & 0.5 & 1.7 & 0.1 & 0.02 & 0.2 & ND & ND & 2.8 \\
\hline 18 & 35 & 0.7 & 0.8 & 1.3 & 0.2 & 0.01 & 0.1 & ND & ND & 3.0 \\
\hline 19 & 39 & 13.3 & 14.1 & 8.6 & 1.0 & 0.01 & 0.1 & 0.54 & 14.8 & 37.5 \\
\hline 20 & 28 & 9.7 & 5.7 & 8.2 & 2.9 & ND & ND & ND & ND & 26.5 \\
\hline 21 & 23 & 37.2 & 12.8 & 7.3 & 1.7 & 0.01 & 0.1 & 0.54 & 14.8 & 59.5 \\
\hline 22 & 21 & 32.2 & 12.4 & 5.8 & 0.8 & ND & ND & 0.29 & 7.9 & 51.5 \\
\hline 23 & 22 & 53.7 & 18.6 & 9.6 & 1.8 & 0.02 & 0.2 & 2.0 & 56.0 & 85.7 \\
\hline 24 & 20 & 31.1 & 5.5 & 2.5 & 0.8 & 0.01 & 0.1 & 0.7 & 20.4 & 40.6 \\
\hline 25 & 85 & 23.3 & 5.2 & 12.9 & 0.8 & 0.01 & 0.1 & 0.16 & 4.4 & 42.4 \\
\hline 26 & 83 & 30.0 & 6.9 & 9.2 & 1.2 & 0.01 & 0.1 & 0.21 & 5.7 & 47.5 \\
\hline 27 & 81 & 27.8 & 15.4 & 8.5 & 0.6 & 0.19 & 1.7 & 0.22 & 6.0 & 52.7 \\
\hline 28 & 114 & 41.2 & 13.9 & 16.7 & 0.7 & ND & ND & 0.11 & 3.1 & 72.6 \\
\hline 29 & 120 & 9.0 & 2.8 & 7.0 & 0.3 & ND & ND & ND & ND & 19.1 \\
\hline 30 & 69 & 89.8 & 76.0 & 127.2 & 0.8 & 0.02 & 0.2 & 0.58 & 16.0 & 294.4 \\
\hline 31 & 46 & 43.2 & 36.0 & 76.5 & 0.4 & 0.01 & 0.1 & 0.18 & 5.2 & 156.3 \\
\hline
\end{tabular}

* Not determined.

$N \mathrm{NH}_{4} \mathrm{OAc}$ minus the quantities in the saturation extract. The CEC was determined as the amount of $\mathrm{Ba}$ adsorbed from a buffered-BaCl solution at $\mathrm{pH}$ 8.0.

The acidity displaced by $N \mathrm{KCl}$ solution was used as an estimate of the acidity exchangeable at the $\mathrm{pH}$ of the soil, and that extracted by $\mathrm{BaCl}_{2}$ buffered at $\mathrm{pH} 8.2$ as a measure of the $\mathrm{pH}$-dependent acidity. The exchange acidity was only a few tenths meq per $100 \mathrm{~g}$ in most soils whereas the $\mathrm{pH}$ dependent acidity ranged from 2.4 to 37 meq per $100 \mathrm{~g}$. Soils $3,9,10$ and 27 , the only ones with any appreciable exchange acidity, contained 1.0, 9.8, 3.2 
and 2.0 meq per $100 \mathrm{~g}$, respectively. The $\mathrm{Al}$ determined in the $\mathrm{KCl}$ extracts of these soils was $0.8,7.8,2.5$ and 1.4 meq per $100 \mathrm{~g}$, respectively. These data suggest that if any appreciable exchange acidity develops in a soil, most of it can be accounted for by measuring the exchangeable Al. Data collected on two soils acidified in a greenhouse experiment show the same trend; at $\mathrm{pH}$

TABLE 4

EXCHANGEABLE CATIONS, INCLUDING EXCHANGE ACIDITY EXTRACTED BY $N \mathrm{KCl}$ AND BY $\mathrm{BaCl}_{2}$ TEA, TOTAL CATIONS AT pH OF THE SOIL AND AT pH 8.2, CEC AT pH 8, AND pH OF THE SOIL

\begin{tabular}{|c|c|c|c|c|c|c|c|c|c|c|}
\hline $\begin{array}{l}\text { Soil } \\
\text { No. }\end{array}$ & $\mathrm{Ca}$ & $\mathbf{M g}$ & $\mathrm{Na}$ & $\mathbf{K}$ & $\begin{array}{c}\text { Exchange } \\
\text { acidity }^{*}\end{array}$ & $\begin{array}{l}\text { Total } \\
\text { cations } \\
\text { at pH } \\
\text { of soil }\end{array}$ & $\begin{array}{c}\mathrm{pH} \text { de- } \\
\text { pendent } \\
\text { acidity } \\
(\mathrm{pH} 8.2) \dagger\end{array}$ & $\begin{array}{c}\text { Total } \\
\text { cations } \\
\text { to } \mathrm{pH} 8.2\end{array}$ & $\begin{array}{c}\text { CEC at } \\
\text { pH } 8.0\end{array}$ & $\mathrm{pH} \ddagger$ \\
\hline & \multicolumn{9}{|c|}{$\mathrm{meq} / 100 \mathrm{~g}$} & \\
\hline 1 & 2.9 & 1.3 & 0.3 & 0.2 & 0.1 & 4.8 & 2.4 & 7.2 & 7.8 & 5.8 \\
\hline 2 & 2.0 & 0.7 & 0.2 & 0.3 & 0.2 & 3.4 & 1.9 & 5.3 & 8.4 & 6.0 \\
\hline 3 & 3.9 & 0.9 & 0.3 & 1.3 & 1.0 & 7.4 & 6.4 & 13.8 & 12.8 & 4.0 \\
\hline 4 & 2.8 & 1.0 & 0.2 & 0.5 & 0.1 & 4.6 & 2.6 & 7.2 & 10.7 & 6.0 \\
\hline 5 & 1.6 & 1.1 & 0.2 & 0.3 & 0.2 & 3.4 & 2.3 & 5.7 & 6.8 & 5.0 \\
\hline 6 & 7.5 & 6.5 & 1.6 & 0.8 & 0.2 & 16.6 & 4.8 & 21.4 & 21.4 & 6.3 \\
\hline 7 & 2.4 & 0.7 & 0.2 & 0.8 & 0.2 & 4.3 & 3.6 & 7.9 & 7.2 & 5.2 \\
\hline 8 & 0.8 & 0.3 & 0.1 & 0.4 & 0.8 & 2.4 & 5.7 & 8.1 & 7.1 & 4.4 \\
\hline 9 & 3.1 & 5.8 & 1.4 & 0.9 & 9.8 & 21.0 & 23.9 & 44.9 & 46.2 & 3.6 \\
\hline 10 & 4.1 & 8.0 & 3.5 & 1.1 & 3.2 & 19.9 & 21.8 & 41.7 & 43.0 & 4.1 \\
\hline 11 & 12.4 & 5.8 & 0.8 & 0.5 & 0.2 & 19.7 & 17.6 & 37.3 & 39.0 & 5.7 \\
\hline 12 & 9.6 & 1.3 & 0.3 & 1.7 & 0.2 & 13.1 & 19.1 & 32.2 & 32.2 & 5.6 \\
\hline 13 & 5.8 & 15.0 & 1.1 & 1.5 & 0.2 & 23.6 & 11.0 & 34.6 & 36.4 & 5.7 \\
\hline 14 & 8.7 & 14.0 & 0.9 & 1.3 & 0.2 & 25.1 & 10.4 & 35.5 & 37.1 & 5.8 \\
\hline 15 & 7.7 & 4.0 & 0.4 & 0.2 & 0.2 & 12.5 & 13.1 & 25.6 & 24.8 & 5.4 \\
\hline 16 & 2.4 & 0.7 & 0.4 & 0.7 & 0.5 & 4.7 & 7.5 & 12.2 & 15.2 & 4.5 \\
\hline 17 & 2.1 & 2.0 & 0.3 & 0.1 & 0.6 & 5.1 & 8.6 & 13.7 & 13.9 & 5.4 \\
\hline 18 & 4.5 & 2.6 & 0.3 & 0.2 & 0.3 & 7.9 & 9.9 & 17.8 & 17.2 & 5.4 \\
\hline 19 & 5.2 & 2.6 & 0.2 & 0.4 & 0.3 & 8.7 & 8.8 & 17.5 & 18.4 & 4.7 \\
\hline 20 & 7.7 & 2.8 & 0.4 & 0.9 & 0.1 & 11.9 & 1.4 & 13.3 & 11.2 & 7.0 \\
\hline 21 & 4.8 & 1.4 & 0.2 & 0.4 & 0.2 & 7.0 & 2.8 & 9.8 & 9.1 & 5.2 \\
\hline 22 & 5.6 & 1.5 & 0.2 & 0.2 & 0.1 & 7.6 & 1.2 & 8.8 & 7.8 & 6.4 \\
\hline 23 & 8.5 & 1.0 & 0.1 & 0.3 & 0.3 & 10.2 & 3.0 & 13.2 & 8.9 & 4.9 \\
\hline 24 & 9.4 & 0.5 & 0.4 & 0.3 & 0.2 & 10.8 & 3.4 & 14.2 & 8.8 & 5.3 \\
\hline 25 & 23.7 & 2.1 & 2.4 & 1.4 & 0.3 & 29.9 & 16.1 & 46.0 & 48.0 & 5.1 \\
\hline 26 & 28.4 & 1.8 & 0.7 & 1.5 & 0.4 & 32.8 & 17.3 & 50.1 & 48.0 & 4.7 \\
\hline 27 & 69.1 & 0.7 & 0.9 & 0.7 & 2.0 & 73.4 & 19.8 & 93.2 & 34.8 & 4.0 \\
\hline 28 & 48.8 & 3.5 & 2.1 & 1.0 & 0.2 & 55.6 & 33.0 & 88.6 & 87.0 & 5.8 \\
\hline 29 & 45.1 & 3.4 & 1.1 & 0.8 & 0.2 & 50.6 & 37.0 & 87.6 & 86.0 & 5.6 \\
\hline 30 & 24.8 & 1.1 & 4.2 & 0.5 & 0.2 & 30.8 & 26.3 & 57.1 & 57.1 & 5.2 \\
\hline 31 & 12.0 & 1.1 & 2.6 & 0.1 & 0.4 & 16.2 & 6.6 & 22.8 & 24.4 & 5.2 \\
\hline
\end{tabular}

* Extracted by $N \mathrm{KCl}$ solution.

$\dagger$ Extracted by $\mathrm{BaCl}_{2}-\mathrm{TEA}$ solution at $\mathrm{pH} 8.2$ following the $\mathrm{KCl}$ extraction.

$\ddagger$ At 1-1 dilution with water.

values of 3.4 and 3.5 the exchange acidities were 5.2 and $5.1 \mathrm{meq}$ per $100 \mathrm{~g}$ and the exchangeable Al values were 4.6 and 4.4 meq per $100 \mathrm{~g}$, respectively.

The sum of the exchangeable cations, including the $\mathrm{pH}$-dependent acidity, greatly exceeded the CEC at $\mathrm{pH} 8.0$ for soil No. 27. A qualitative test showed that gypsum was present in this soil. There was also rather poor agreement between the sum of the cations and $\mathrm{CEC}$ for several soils with CEC values of about 10 or less meq per $100 \mathrm{~g}$, but for all other soils these two values were in excellent agreement. 
The relations between $\mathrm{pH}$ and base saturation (saturation with the cations $\mathrm{Na}, \mathrm{K}, \mathrm{Ca}$ and $\mathrm{Mg}$ ) as per cent of the total exchangeable cations at the $\mathrm{pH}$ of the soil, and as per cent of total cations to $\mathrm{pH} 8.2$ are presented in figure 1 . If the sum of the cations at the $\mathrm{pH}$ of the soil is used as a reference point, all the soils were, for all practical purposes, base-saturated at $\mathrm{pH}$ values of 5 and above. But, if the sum of the total cations to $\mathrm{pH} 8.2$ is used, all soils were



Fig. 1. Relations between $\mathrm{pH}$ and base saturation as per cent of the CEC at the $\mathrm{pH}$ of the soil and base saturation as per cent of the CEC at $\mathrm{pH} 8.2$.

unsaturated. There is a closer relationship between base saturation and $\mathrm{pH}$ when the sum of exchangeable cations at the $\mathrm{pH}$ of the soils is considered than when the sum of the cations at $\mathrm{pH} 8.2$ is taken as a reference point.

The linear correlation between exchangeable $\mathrm{Na}$ ratio (exchangeable $\mathrm{Na} / \mathrm{CEC}$-exchangeable $\mathrm{Na})$ and the $\mathrm{SAR}(\mathrm{Na} / \mathrm{V} \mathrm{Ca}+\mathrm{Mg}$ with the concentrations expressed in mmole/l) of the saturation extract was 0.89 , with a regression equation of $\mathrm{Y}=0.023+0.0098 \mathrm{X}$. Corresponding values given in Agriculture Handbook No. 60 (1954) of the U. S. Salinity Laboratory are $\mathrm{r}=0.923$ and $\mathrm{Y}=-0.0123+0.01475 \mathrm{X}$. While the regression equations differ to some extent, the data given here and that presented by the Salinity 
Laboratory are similar over the relatively narrow range of SAR values $(0.6$ to 20) in this report. The CEC values used in calculating the exchangeable $\mathrm{Na}$ ratio were assumed to be the sum of the total exchangeable cations at the $\mathrm{pH}$ of the soil as listed in column 7 of table 4 .

The exchange constant for the reaction $\mathrm{Mg}$-soil $+\mathrm{Ca}^{++} \rightleftharpoons \mathrm{Ca}$-soil $+\mathrm{Mg}^{++}$ was calculated from data on the saturation extract and the exchangeable

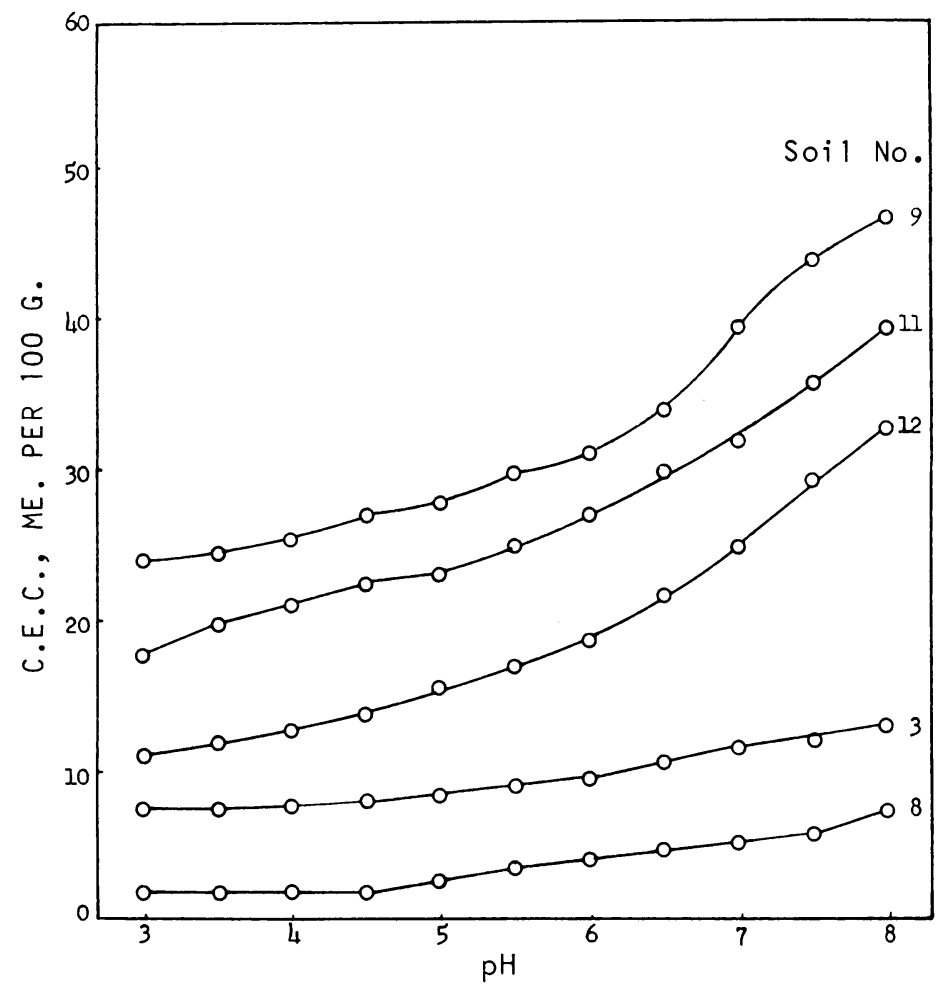

Fig. 2. Relations between cation-exchange capacity and $\mathrm{pH}$ for five soils.

cations. The constant averaged 1.76 with a range of values from 1.18 to 2.52. The data indicate that considerable error might be involved in calculating exchangeable $\mathrm{Mg}$ and $\mathrm{Ca}$ by using an average exchange constant and the saturation extract data, as was done by Pratt and Harding (1957) and McColloch et al. (1957); however, the relative values calculated for various samples of the same soil might be reliable.

\section{CATION-EXCHANGE CAPACITY}

Recent investigations (Schofield 1950 and Coleman et al. 1959) have shown that soils and clays have a $\mathrm{pH}$-dependent component of the CEC. In order to measure this $\mathrm{pH}$-dependent component, and also to verify that the sum of the cations at the $\mathrm{pH}$ of the soil represents the capacity to adsorb cations at that $\mathrm{pH}$, a method was developed for measuring the $\mathrm{CEC}$ over a $\mathrm{pH}$ range from 3 to 8 . 
Method. A 2.5-g sample of soil was washed with 25 -ml portions of a buffer solution until the $\mathrm{pH}$ was constant. The buffer solution contained $18.5 \mathrm{~g}$ $\mathrm{Ba}(\mathrm{OAc})_{2} \cdot \mathrm{H}_{2} \mathrm{O}, 80 \mathrm{~g} \mathrm{BaCl}{ }_{2} \cdot 2 \mathrm{H}_{2} \mathrm{O}, 2.18 \mathrm{~g}$ p-nitrophenol, and $7.5 \mathrm{ml}$ of triethanolamine per liter and was adjusted to $\mathrm{pH}$ values of 3 to 8 with $\mathrm{HCl}$. The sample was then washed with four 25 -ml portions of $0.5 \mathrm{~N} \mathrm{BaCl}_{2}$ solution containing $2 \mathrm{ml}$ of the appropriate buffer per $100 \mathrm{ml}$ of $\mathrm{BaCl}_{2}$ solution and adjusted to the $\mathrm{pH}$ of the buffer by adding TEA or HCl. The excess salt was

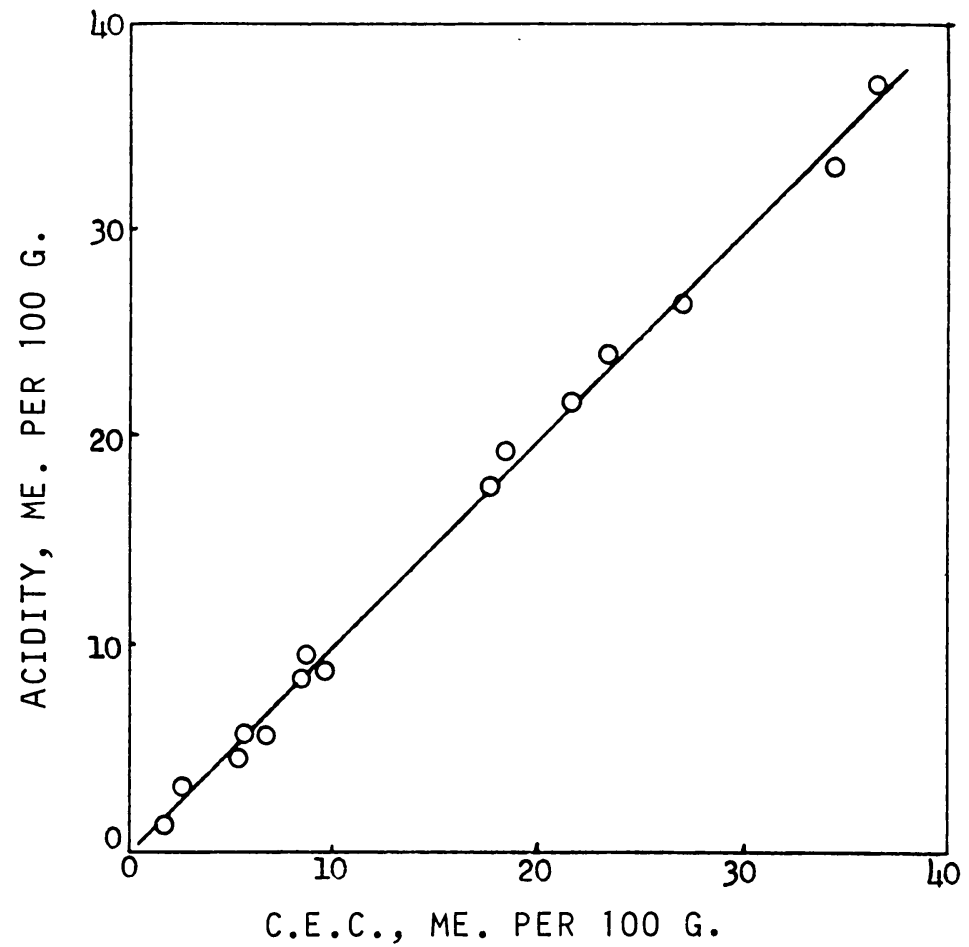

Fig. 3. Relation between $\mathrm{pH}$-dependent acidity and $\mathrm{pH}$-dependent cation-exchange capacity as measured by the difference in cation-exchange capacity at $\mathrm{pH} 8.2$ and at the $\mathrm{pH}$ of a 1 to 5 suspension of soil in $N \mathrm{KCl}$.

removed by washing with methyl alcohol and the alcohol was removed by heating the sample in a water bath. The adsorbed $\mathrm{Ba}$ was replaced with neutral $N \mathrm{NH}_{4} \mathrm{OAc}$ solution and the Ba determined flame-photometrically. The CEC was calculated from the $\mathrm{Ba}$ in the $\mathrm{NH}_{4} \mathrm{OAc}$ extract.

Results. The relations between the CEC and $\mathrm{pH}$ for five soils are shown in figure 2. Similar data, obtained on nine other soils, are not presented because the curves obtained had the same characteristics as those in figure 2. Data on some soils showed a continuous change in CEC with change in $\mathrm{pH}$ while data on others showed a constant value between $\mathrm{pH} 3$ and 4.5 with increases as the $\mathrm{pH}$ increased from 4.5 to 8.0.

If the reduction in $\mathrm{CEC}$ obtained as the $\mathrm{pH}$ decreased is a result of association of $\mathrm{H}^{+}$ions with exchange radicals such that the radicals no longer 
carry a negative charge, one should be able to obtain, independently, a measure of the $\mathrm{pH}$-dependent $\mathrm{CEC}$ by measuring the $\mathrm{H}^{+}$ions displaced by a salt solution buffered at the higher $\mathrm{pH}$ value. This means that the difference in CEC between $\mathrm{pH} 8.2$ and the $\mathrm{pH}$ of the soil suspended in $N \mathrm{KCl}$ solution should be equivalent to the $\mathrm{pH}$-dependent acidity as measured by extraction with $\mathrm{BaCl}_{2}$-triethanolamine (at $\mathrm{pH} 8.2$ ) following extraction with $\mathrm{KCl}$. Data in figure 3 show this to be the case for the 15 soils. The agreement between the two values indicates that they are estimates of the same thing, i.e., the change in $\mathrm{CEC}$ with change in $\mathrm{pH}$.

TABLE 5

CEC AT pH 8.0, pH-DEPENDENT CEC OF SOIL AND OF CLAY SEPARATED FROM THE SOIL, AND CONTRIBUTION OF CLAY AND ORGANIC C TO THE pH-DEPENDENT CEC OF THE SOIL

\begin{tabular}{|c|c|c|c|c|c|c|}
\hline \multirow[t]{2}{*}{$\begin{array}{l}\text { Soil } \\
\text { No. }\end{array}$} & $\begin{array}{c}\mathrm{CEC} \text { at } \\
\mathrm{pH} 8\end{array}$ & $\begin{array}{c}\mathrm{pH}-\text { dependent } \\
\text { CEC of soil }\end{array}$ & $\begin{array}{l}\text { pH.dependent } \\
\text { CEC of clay }\end{array}$ & $\begin{array}{l}\text { Contribution } \\
\text { of clay to } \\
\text { pH-dependent } \\
\text { CEC of soil* }\end{array}$ & $\begin{array}{l}\text { Contribution } \\
\text { of organic C } \\
\text { to pH-depend- } \\
\text { ent CEC of soil }\end{array}$ & $\begin{array}{l}\text { pH- } \\
\text { dependent } \\
\text { CEC of } \\
\text { organic C }\end{array}$ \\
\hline & \multicolumn{2}{|c|}{$m e q / 100 \mathrm{~g}$} & meq/100 g clay & \multicolumn{2}{|c|}{ meq $/ 100 \mathrm{~g}$ soil } & $m e q / 100 \mathrm{~g}$ \\
\hline $3 \ldots \ldots \ldots$ & 12.8 & 5.7 & 17.0 & 2.4 & 3.3 & 470 \\
\hline $6 \ldots \ldots \ldots \ldots$ & 21.4 & 6.6 & 11.2 & 3.6 & 3.0 & 210 \\
\hline $8 \ldots \ldots \ldots \ldots$ & 7.1 & 5.3 & 13.0 & 1.2 & 4.1 & 380 \\
\hline $9 \ldots \ldots \ldots \ldots$ & 46.2 & 22.4 & 13.9 & 6.0 & 16.4 & 480 \\
\hline $10 \ldots \ldots \ldots \ldots$ & 43.0 & 20.6 & 13.9 & 6.8 & 13.8 & 370 \\
\hline $11 \ldots \ldots \ldots$ & 39.0 & 21.6 & 16.7 & 7.0 & 14.5 & 430 \\
\hline $12 \ldots \ldots \ldots \ldots$ & 32.2 & 21.3 & 24.2 & 6.8 & 14.5 & 450 \\
\hline $17 \ldots \ldots \ldots \ldots$ & 13.9 & 8.6 & 13.0 & 2.0 & 6.6 & 280 \\
\hline $22 \ldots \ldots \ldots \ldots$ & 7.8 & 2.5 & 13.0 & 1.2 & 1.3 & 650 \\
\hline $23 \ldots \ldots \ldots$ & 8.9 & 2.5 & 13.0 & 1.4 & 1.1 & 280 \\
\hline $28 \ldots \ldots$ & 87.0 & 47.4 & 20.5 & 9.7 & 37.7 & 260 \\
\hline $29 \ldots \ldots$ & 86.0 & 48.1 & 18.6 & 8.8 & 39.3 & 260 \\
\hline $30 \ldots \ldots \ldots \ldots$ & 57.1 & 33.0 & 16.8 & 4.3 & 28.7 & 300 \\
\hline Average... & $\ldots$ & $\ldots$ & 15.8 & $\ldots$ & $\ldots$ & 370 \\
\hline
\end{tabular}

* Assuming the clay and organic $\mathrm{C}$ contributed independently to the $\mathrm{pH}$-dependent cation-exchange capacity of the soil.

Table 5 presents data for the CEC of the soil at $\mathrm{pH} 8$, the $\mathrm{pH}$-dependent CEC (difference between $\mathrm{pH} 8$ and $\mathrm{pH} 3$ ) of the soil, and of the clay separated from the soil, and the contribution of clay and organic $\mathrm{C}$ to the $\mathrm{pH}$ dependent CEC of the soil. It is assumed that the clay and organic $\mathrm{C}$ contribute independently, an assumption that may not be justified but allows a calculation of the relative effects of clay and organic matter on the $\mathrm{pH}$ dependent CEC of the soil. Per unit weight of material, the organic C contributes about 24 times more than the clay.

Russell (1950) presented data showing that a montmorillonite clay had a CEC of 95 meq per $100 \mathrm{~g}$ in the $\mathrm{pH}$ range of 2.5 to 6 but the value increased to 100 meq per $100 \mathrm{~g}$ at $\mathrm{pH}$ 7.0. The $\mathrm{pH}$-dependent CEC for a montmorillonite clay, as determined by the method used for this paper, was 97,102 , and 104 meq per $100 \mathrm{~g}$ for $\mathrm{pH} \mathrm{3,7}$ and 8, respectively. The $\mathrm{pH}$-dependent cationexchange capacity to $\mathrm{pH} 7$ was 5 meq per $100 \mathrm{~g}$, which is nearly the same value as reported by Russell. 
The $\mathrm{pH}$-dependent $\mathrm{CEC}$ ( $\mathrm{pH} 3$ to 8 ) of clays separated from the soils used in this study varied from 11.2 to 24.2 meq per $100 \mathrm{~g}$; however, 8 of the 15 values were between 13 and 15 meq. If Schofield's (1950) data for a clay subsoil are extrapolated to $\mathrm{pH} 8$, the calculated $\mathrm{pH}$-dependent $\mathrm{CEC}$ of the clay in the soil is about 15 meq per $100 \mathrm{~g}$. This figure is based on a clay content of 60 per cent calculated from the ratio of the $\mathrm{CEC}$ of the clay to that of the soil. Thus, the $\mathrm{pH}$-dependent $\mathrm{CEC}$ or the relation between $\mathrm{CEC}$ and $\mathrm{pH}$ of clays, as measured by the method herein described, agrees well with data from other sources.

\section{SODIUM-CALCIUM EXCHANGE EQUILIBRIA}

Because a number of the acid soils collected contained large amounts of $\mathrm{Na}$ and $\mathrm{Ca}$ salts, a measurement of the effect of $\mathrm{pH}$ on relative adsorption of $\mathrm{Na}$ and $\mathrm{Ca}$ was considered desirable. The specific information wanted concerned the change in ratio of $\mathrm{Na}$ adsorption to $\mathrm{Ca}$ adsorption as the $\mathrm{CEC}$ decreased with decrease in $\mathrm{pH}$.

The double-layer equation derived by Eriksson (1952) has been used by Bolt (1955) and Bower (1959) to study the adsorption of $\mathrm{Na}$ and $\mathrm{Ca}$ ions from salt solutions. The equation, which is based on the Poisson-Boltzmann differential equation, shows the charge fraction of monovalent to total ions in the diffuse double-layer of a plate-like exchanger as a function of the concentration of monovalent and divalent ions in the solution. The equation as simplified by Bolt (1955) is:

$$
\Gamma_{1} / \Gamma=\frac{\mathrm{r}}{\Gamma \vee \gamma \beta} \sinh ^{-1} \frac{\Gamma \vee \beta}{\mathrm{r}+4 \mathrm{v}_{\mathrm{c}} \vee \mathrm{c}_{2}}
$$

where $\Gamma$ is the surface charge density of the exchanger in meq per $\mathrm{cm}^{2}, \Gamma_{1} / \Gamma$ is, in the use of the equation, the fraction of surface charge that is neutralized by monovalent cations, $r=c_{1} / V c_{2}(\text { mole } / 1)^{\frac{1}{2}}$ where $c_{1}$ and $c_{2}$ are the molar concentrations of the monovalent and divalent cations, respectively, $\beta=1.06 \times 10^{15} \mathrm{~cm} / \mathrm{mmole}$ at $25^{\circ} \mathrm{C}$ and $\mathrm{v}_{\mathrm{c}}=1$.

To calculate data for the theoretical curves shown in figures 4,5 and 6 , actual values for $\Gamma$ and $r$ were put into the equation and $\Gamma_{1} / \Gamma$ values were obtained. The data were then recalculated in terms of $\Gamma_{1} / \Gamma-\Gamma_{1}$ or $\mathrm{Na}_{\mathrm{ad}} / \mathrm{Ca}_{\mathrm{ad}}$ and $\mathrm{SAR}$ or $\mathrm{Na} / \mathrm{VCa},(\mathrm{mmoles} / \mathrm{L})^{\frac{1}{2}}$. In figure 5 the $\Gamma$ for the soil was multiplied by 2.1 to obtain an adjusted $\Gamma$ that was put into the equation. The value 2.1 was obtained by measurements of the departure of the theoretical data from the experimental data.

Bolt (1955) found that this double-layer equation adequately described the equilibrium of a Na-Ca-illite in solutions of $\mathrm{NaCl}$ and $\mathrm{CaCl}_{2}$ when the determined value of surface charge density was multiplied by 1.2 , and Bower (1959) found agreement between the equation and experimental data for four soils and two clays when the surface charge densities were multiplied by 1.4. A recent report by Lunin and Batchelder (1961) showed that the ratio of $\mathrm{Na}$ adsorbed to $\mathrm{Ca}$ adsorbed increased with decrease in $\mathrm{pH}$ of soils.

Coleman et al. (1959) have shown that at $\mathrm{pH}$ values of 5 and above, soils have only small amounts of acidity exchangeable with neutral salts, i.e., soils with pH 5 and above are essentially base-saturated, but they increase in basic 
cation adsorption as a result of increase in CEC with increase in $\mathrm{pH}$. Thus, if the double-layer equation applies at $\mathrm{pH} 8$, it should apply equally well at any other $\mathrm{pH}$ within the range of 5 to 8 if the surface charge density appropriate to the $\mathrm{pH}$ of equilibrium condition is used.

Methods. Buffers for $\mathrm{pH} 5,6,7$ and 8 were prepared. Each buffer contained $0.71 \mathrm{~g}$ of $\mathrm{Ca}(\mathrm{OAc})_{2} \cdot \mathrm{H}_{2} \mathrm{O}, 2.18 \mathrm{~g}$ of p-nitrophenol and sufficient $\mathrm{NaCl}$ to give the desired $\mathrm{Na}$ concentration. Before dilution to 1.0 liter the $\mathrm{pH}$ was adjusted to the desired values by adding triethanolamine or acetic acid. The $\mathrm{Ca}(\mathrm{OAc})_{2} \cdot \mathrm{H}_{2} \mathrm{O}$ added was sufficient to give 4.0 mmoles $\mathrm{Ca}$ per liter, and buffers were prepared for $\mathrm{Na}$ concentrations of 40,80,120,160 and 200 mmoles per liter for each $\mathrm{pH}$ value.

A $2.5 \mathrm{~g}$ or $5.0 \mathrm{~g}$ sample of soil was washed 4 times with a $25 \mathrm{ml}$ portion of the appropriate buffer solution. The 4 washings were always sufficient to bring the $\mathrm{pH}$ of the soil suspension to the $\mathrm{pH}$ of the buffer. The soil sample was then washed with $25 \mathrm{ml}$ portions of a diluted buffer solution containing the same $\mathrm{Ca}$ and $\mathrm{Na}$ concentrations as the concentrated buffer solution. This solution, containing only 2 per cent as much of the buffering reagents and adjusted to the same $\mathrm{pH}$ as the buffer, was used to displace most of the buffer reagents from the soil, maintaining at the same time the desired $\mathrm{pH}$. Washing with the diluted buffer was continued until equilibrium was indicated by the same $\mathrm{Ca}$ and $\mathrm{Na}$ concentrations in the wash solution as in the original solution. Equilibrium was attained by 10 washings in most cases, but some soils with high CEC required 13 washings.

After equilibrium was attained the sample was washed with $\mathrm{NH}_{4} \mathrm{OAc}$, and the $\mathrm{Ca}, \mathrm{Na}$ and $\mathrm{Cl}$ in the $\mathrm{NH}_{4} \mathrm{OAc}$ extract were determined. The $\mathrm{Na}$ was determined flame-photometrically. The $\mathrm{Ca}$ was titrated with versenate following oxidation of the $\mathrm{NH}_{4} \mathrm{OAc}$ in the muffle furnace, and the $\mathrm{Cl}$ was titrated with standard $\mathrm{Hg}\left(\mathrm{NO}_{3}\right)_{2}$ following an $\mathrm{H}_{2} \mathrm{O}_{2}$ oxidation of the $\mathrm{NH}_{4} \mathrm{OAc}$ in the presence of a small amount of $\mathrm{CaO}$ to prevent loss of $\mathrm{Cl}$.

The adsorbed $\mathrm{Na}$ and $\mathrm{Ca}$ were determined as the total in the $\mathrm{NH}_{4} \mathrm{OAc}$ minus the correction for quantities present as $\mathrm{Cl}$ salts. The proportions of $\mathrm{Na}$ and $\mathrm{Ca}$ present as $\mathrm{Cl}$ salts were assumed to be the same as in the final washing with replacement solution.

The Na-Ca equilibria, with the use of a Ca concentration of $0.004 M$ with variable $\mathrm{Na}$ concentrations, were measured on ten soils. In addition, the $\mathrm{Na}-\mathrm{Ca}$ equilibria, with the use of $0.10 M$ and $0.20 \mathrm{M} \mathrm{Na}$ with variable $\mathrm{Ca}$ concentrations, were measured on one soil.

Surface area measurements were made by ethylene glycol retention (Bower and Goertzen, 1959). The CEC values used to obtain the surface charge density were obtained by the method described previously.

Results. Figures 4 and 5 present relations among the ratio of adsorbed $\mathrm{Na}$ to adsorbed $\mathrm{Ca}, \mathrm{Na}$ and $\mathrm{Ca}$ in solution and $\mathrm{pH}$ of the solution of soils 8 and 12 , respectively. The solid lines in the figures represent the theoretical relations, as calculated from the double-layer equation, and the circles represent experimental data.

With soil 8, the double-layer equation satisfactorily predicted the ratio of adsorbed $\mathrm{Na}$ to $\mathrm{Ca}$ at all four $\mathrm{pH}$ values. At an $\mathrm{SAR}$ value of 100 the ratio of $\mathrm{Na}$ to $\mathrm{Ca}$ in the adsorbed state increased from 0.89 at $\mathrm{pH} 8$ to 2.42 at $\mathrm{pH} 5$. 
The actual values for surface charge density were used in the double-layer equation and no factor such as that used by Bolt (1955) and by Bower (1959) was necessary. Soil 3 was similar to 8 in that the equation predicted the experimental data without using a correction factor for the surface charge density.

The experimental data on soil 12 agreed with the equation when the surface charge density was multiplied by 2.1 . However, the same correction was

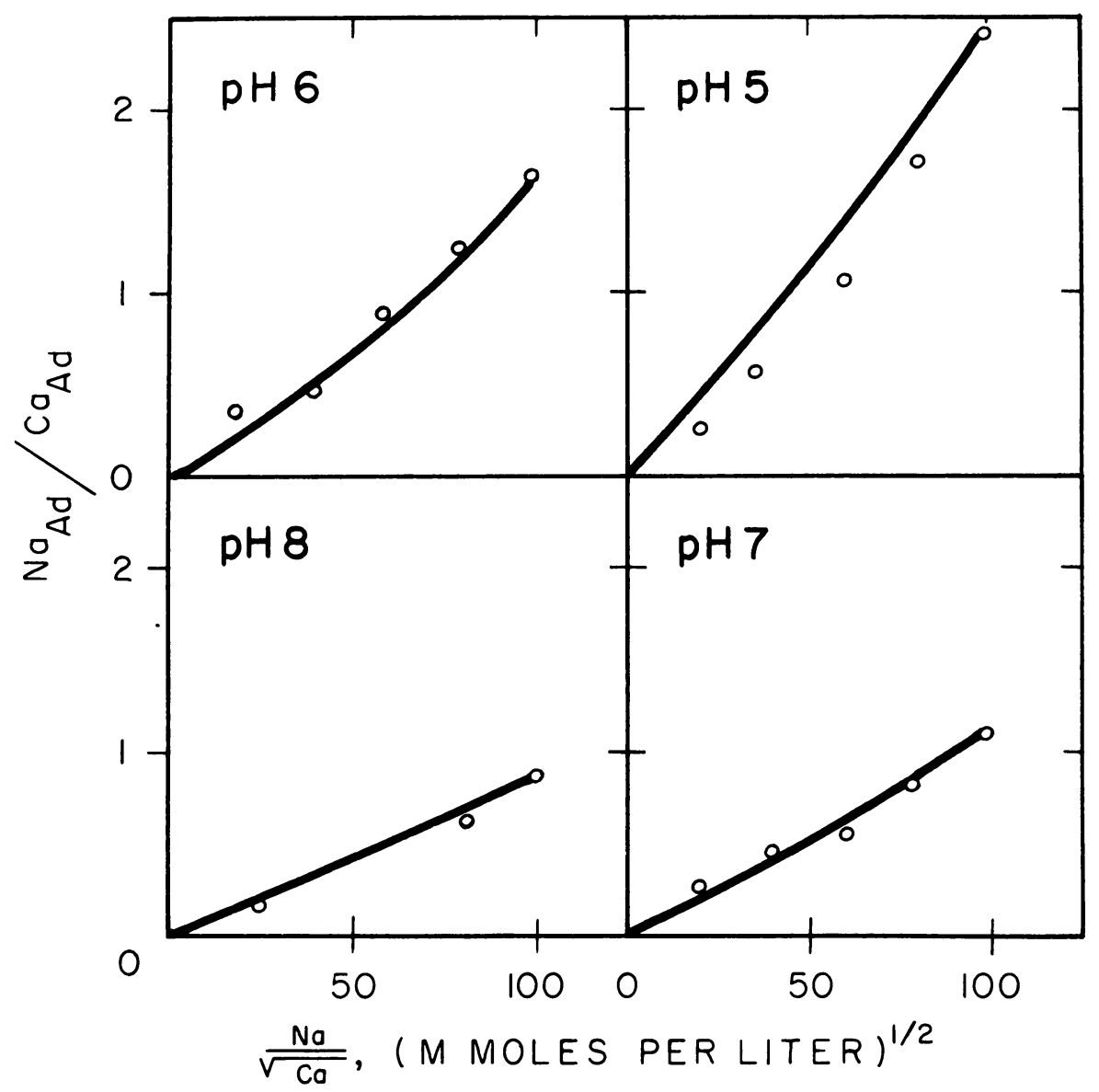

Fig. 4. Relations among the ratio of adsorbed $\mathrm{Na}$ to adsorbed $\mathrm{Ca}, \mathrm{Na}$ and $\mathrm{Ca}$ in solution and $\mathrm{pH}$ of the solution for soil 8 . Solid lines represent the theoretical relations and the circles represent experimental data.

needed at all four $\mathrm{pH}$ values, and thus the equation predicted the relative change in $\mathrm{Na}$ to $\mathrm{Ca}$ ratios with change in surface charge density associated with variations in $\mathrm{pH}$. The agreement of the experimental data with the theoretical line was essentially independent of the total concentration of $\mathrm{Na}$ and $\mathrm{Ca}$ in solution. The data obtained with use of a high constant concentration of $\mathrm{Na}$ and a variable $\mathrm{Ca}$ concentration fit the line, as well as those ob- 
tained with use of a low constant $\mathrm{Ca}$ concentration and a variable $\mathrm{Na}$ concentration.

Data on 7 other soils were similar to those in figure 5 in that the equation and the experimental data agreed well when the surface charge densities were multiplied by an appropriate factor. Thus, with ten soils on which detailed data were obtained, the theoretical equation predicted the relative

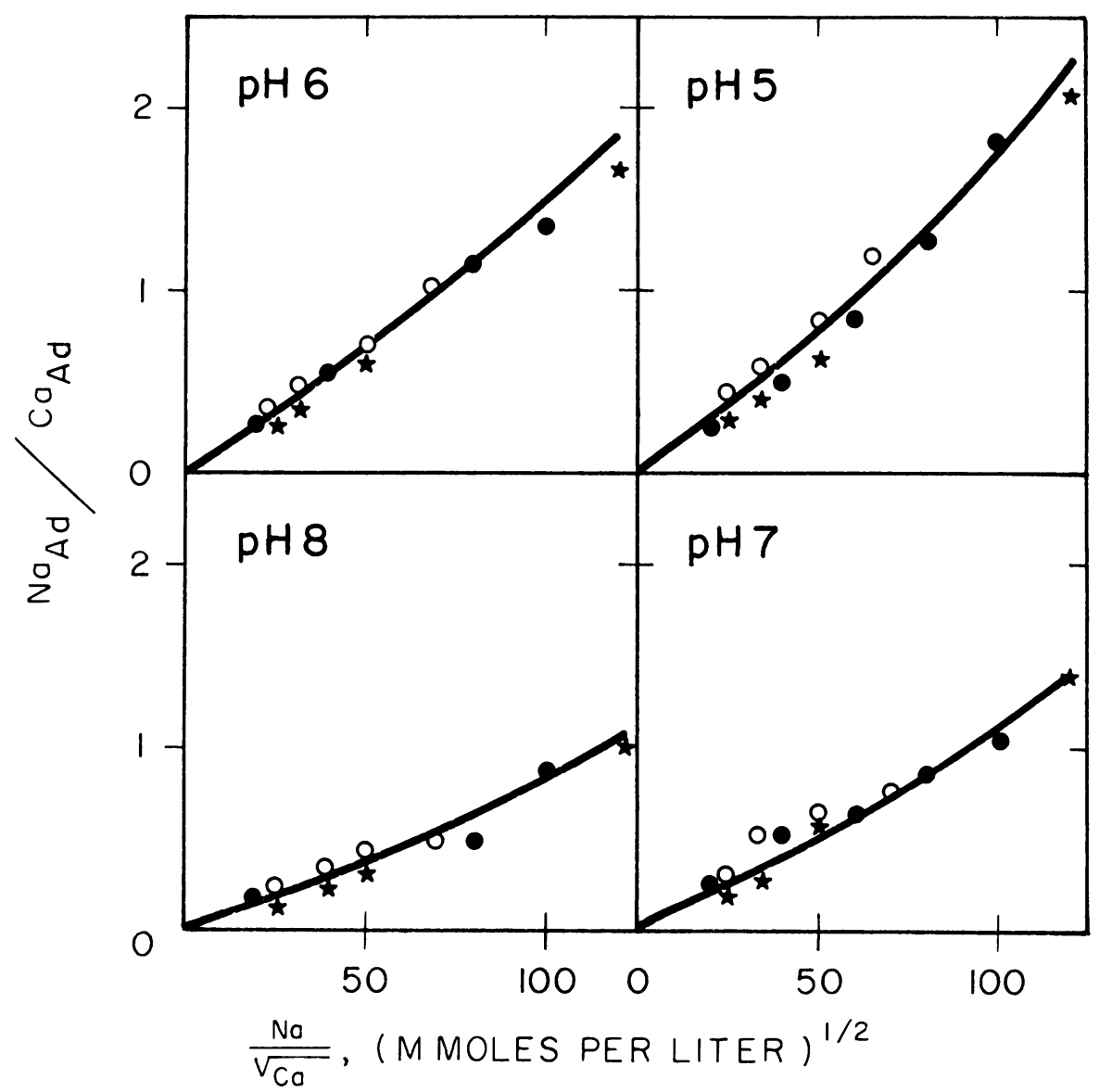

Fig. 5. Relations among the ratio of adsorbed $\mathrm{Na}$ to adsorbed $\mathrm{Ca}, \mathrm{Na}$ and $\mathrm{Ca}$ in solution and $\mathrm{pH}$ of the solution for soil 12 . The lines represent the theoretical relations, the solid circles represent data for $0.004 M$ Ca with variable $\mathrm{Na}$ concentrations, the open circles represent data for $0.10 \mathrm{M} \mathrm{Na}$ with variable Ca concentrations, and the stars represent data with $0.20 \mathrm{M} \mathrm{Na}$ and variable $\mathrm{Ca}$ concentrations.

change in ratio of $\mathrm{Na}$ to $\mathrm{Ca}$ adsorption with change in $\mathrm{pH}$ over a range of $\mathrm{pH}$ values from 5 to 8 inclusive.

The relations between the ratio of adsorbed $\mathrm{Na}$ to adsorbed $\mathrm{Ca}$ and the surface charge density for seven soils are presented in figure 6 . The equilibrium solutions (fig. 6) had SAR values of 100 ; data on three other soils were so similar to those shown that they were omitted to avoid confusion. 
The curve for each soil is of the same type as the theoretical curve but is displaced, to the left, by a constant.

Data on exchangeable $\mathrm{Na}$ and $\mathrm{Ca}$ and relative amounts of adsorbed $\mathrm{Na}$ and $\mathrm{Ca}$, in relation to $\mathrm{pH}$ of an equilibrium solution containing an SAR of 100 for five soils, are presented in table 6 . With four of the soils, the amount of adsorbed $\mathrm{Na}$ decreased as the $\mathrm{pH}$ increased, but with soil 13 it increased

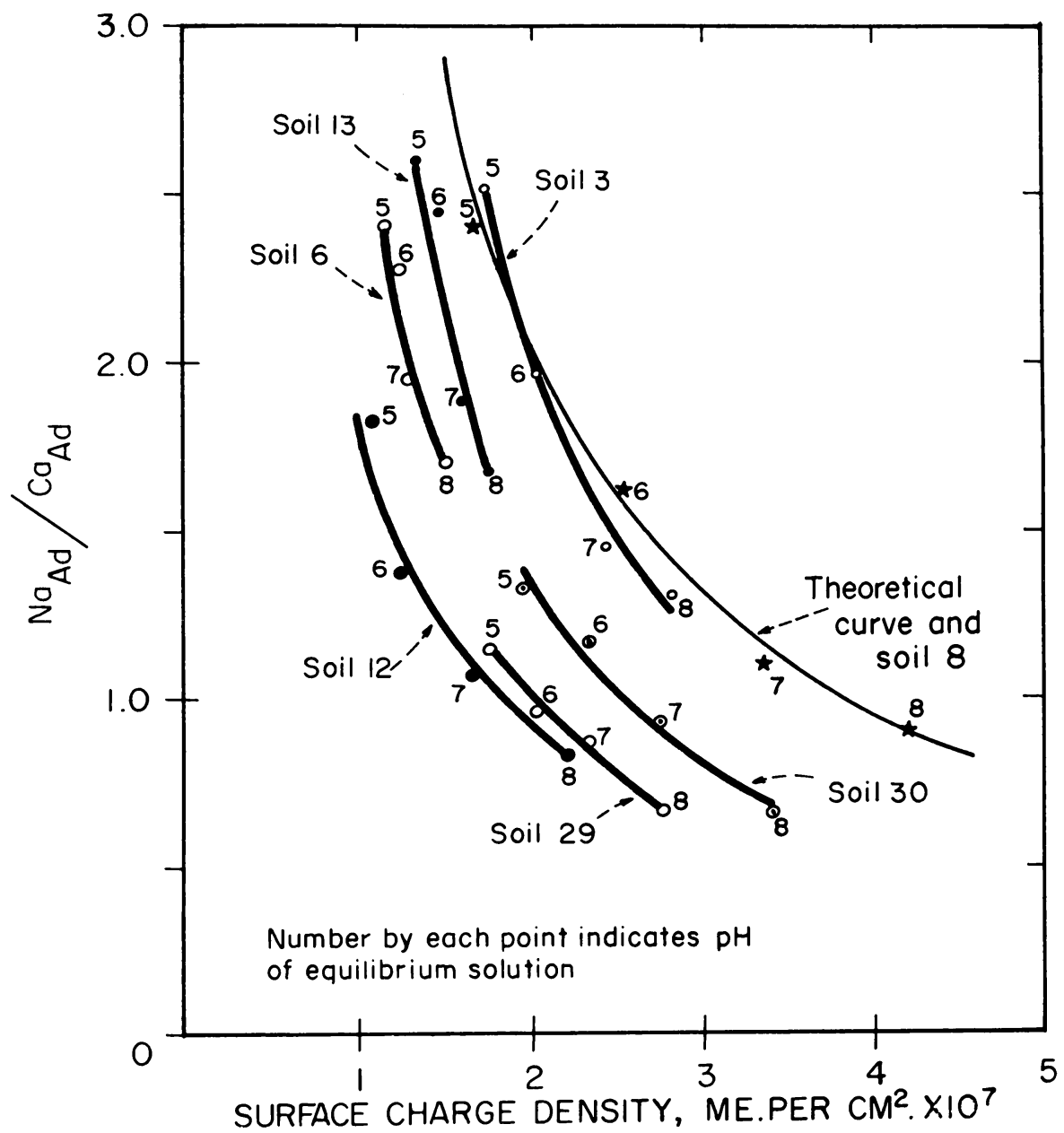

Fig. 6. Relations between the ratio of adsorbed $\mathrm{Na}$ to adsorbed $\mathrm{Ca}$ and the surface charge density for seven soils. The equilibrium solution had an SAR of 100 .

slightly. In all cases the adsorbed $\mathrm{Ca}$ decreased with decrease in $\mathrm{pH}$, to a greater degree than Na. Thus, as the $\mathrm{pH}$ decreased with a loss in CEC, the reduction in $\mathrm{Ca}$ was greater than the reduction in Na adsorption.

The double-layer equation as presented by Bolt (1955) seems to describe, satisfactorily, the relative change in the ratio of $\mathrm{Na}$ to $\mathrm{Ca}$ adsorption, with change in $\mathrm{pH}$ of equilibrium solutions containing $\mathrm{Cl}$ salts of these two cations. 
The method of measuring relative CEC with change in $\mathrm{pH}$ also seems to be valid. However, the large variation in correction factors for the surface charge density, necessary to make the experimental data agree with the equation, suggest that something is either inherently wrong with one or both of the experimental determinations leading to the values of surface charge density, or that the soils have rather wide differences in the specificity with which they adsorb $\mathrm{Ca}$ vs. Na ions.

TABLE 6

EXCHANGEABLE Na AND Ca AND RELATIVE ADSORPTION OF Na AND Ca IN RELATION TO THE $\mathrm{pH}$ OF AN EQUILIBRIUM SOLUTION CONTAINING AN SAR OF 100

\begin{tabular}{|c|c|c|c|c|c|}
\hline \multirow{2}{*}{ Soil } & \multirow{2}{*}{$\mathrm{pH}$} & \multicolumn{2}{|c|}{ Exchangeable } & \multicolumn{2}{|c|}{ Relative adsorption } \\
\hline & & $\mathrm{Na}$ & $\mathrm{Ca}$ & $\mathrm{Na}$ & $\mathrm{Ca}$ \\
\hline \multirow{5}{*}{3} & & \multicolumn{2}{|c|}{ meq/g } & & \\
\hline & $8 \ldots$ & 0.075 & 0.047 & 100 & 100 \\
\hline & $7 \ldots$ & 0.058 & 0.037 & 77 & 79 \\
\hline & $6 \ldots$ & 0.057 & 0.026 & 76 & 55 \\
\hline & $5 \ldots \ldots$ & 0.048 & 0.018 & 64 & 38 \\
\hline \multirow[t]{4}{*}{8} & $8 \ldots$ & 0.024 & 0.029 & 100 & 100 \\
\hline & $7 \ldots$ & 0.017 & 0.020 & 71 & 69 \\
\hline & $6 \ldots \ldots \ldots$ & 0.019 & 0.011 & 79 & 38 \\
\hline & $5 \ldots$ & 0.018 & 0.007 & 75 & 24 \\
\hline \multirow[t]{4}{*}{12} & $8 \ldots$ & 0.118 & 0.147 & 100 & 100 \\
\hline & $7 \ldots$ & 0.112 & 0.101 & 95 & 69 \\
\hline & $6 \ldots$ & 0.098 & 0.076 & 83 & 52 \\
\hline & $5 \ldots \ldots$ & 0.087 & 0.051 & 74 & 35 \\
\hline \multirow[t]{4}{*}{19} & $8 \ldots$ & 0.090 & 0.090 & 100 & 100 \\
\hline & $7 \ldots$ & 0.078 & 0.072 & 86 & 80 \\
\hline & $6 \ldots \ldots$ & 0.079 & 0.056 & 88 & 62 \\
\hline & $5 \ldots$ & 0.073 & 0.039 & 81 & 43 \\
\hline \multirow[t]{4}{*}{13} & 다. & 0.194 & 0.104 & 100 & 100 \\
\hline & $7 \ldots$ & 0.210 & 0.095 & 108 & 91 \\
\hline & $6 \ldots$ & 0.210 & 0.085 & 108 & 82 \\
\hline & $5 \ldots$ & 0.207 & 0.076 & 107 & 73 \\
\hline
\end{tabular}

The method of measuring the $\mathrm{CEC}$ was found to give CEC values in agreement with the sum of the exchangeable cations in the soils used in this study; therefore, there seems to be nothing inherently wrong in this determination.

The surface area data used were averages of three different determinations. Although there were variations among these, the magnitude of the variations was of the order of 10 per cent departure from the mean, and could not account for the range in correction factors needed. Thus, the analytical error in the surface area determination is not at fault. There is a possibility, however, that included in the surface area were various types of surfaces which contributed little or nothing to the CEC of the soil. Various minerals of the clay fraction such as quartz, feldspar and amorphous oxides of $\mathrm{Fe}, \mathrm{Al}$ and $\mathrm{Ti}$ would probably contribute to the surface area without adding much to the 
CEC. Also, certain organic colloids might behave in a similar manner. This would mean that the surface charge is not uniformly distributed on the total surface area but is confined to certain surfaces. Thus, the correction factor would seem to adjust the average surface charge density to the surface areas on which it exists.

Since the specificity with which Ca vs. Na is adsorbed is directly related to the surface charge density, the explanation for the correction factors, as

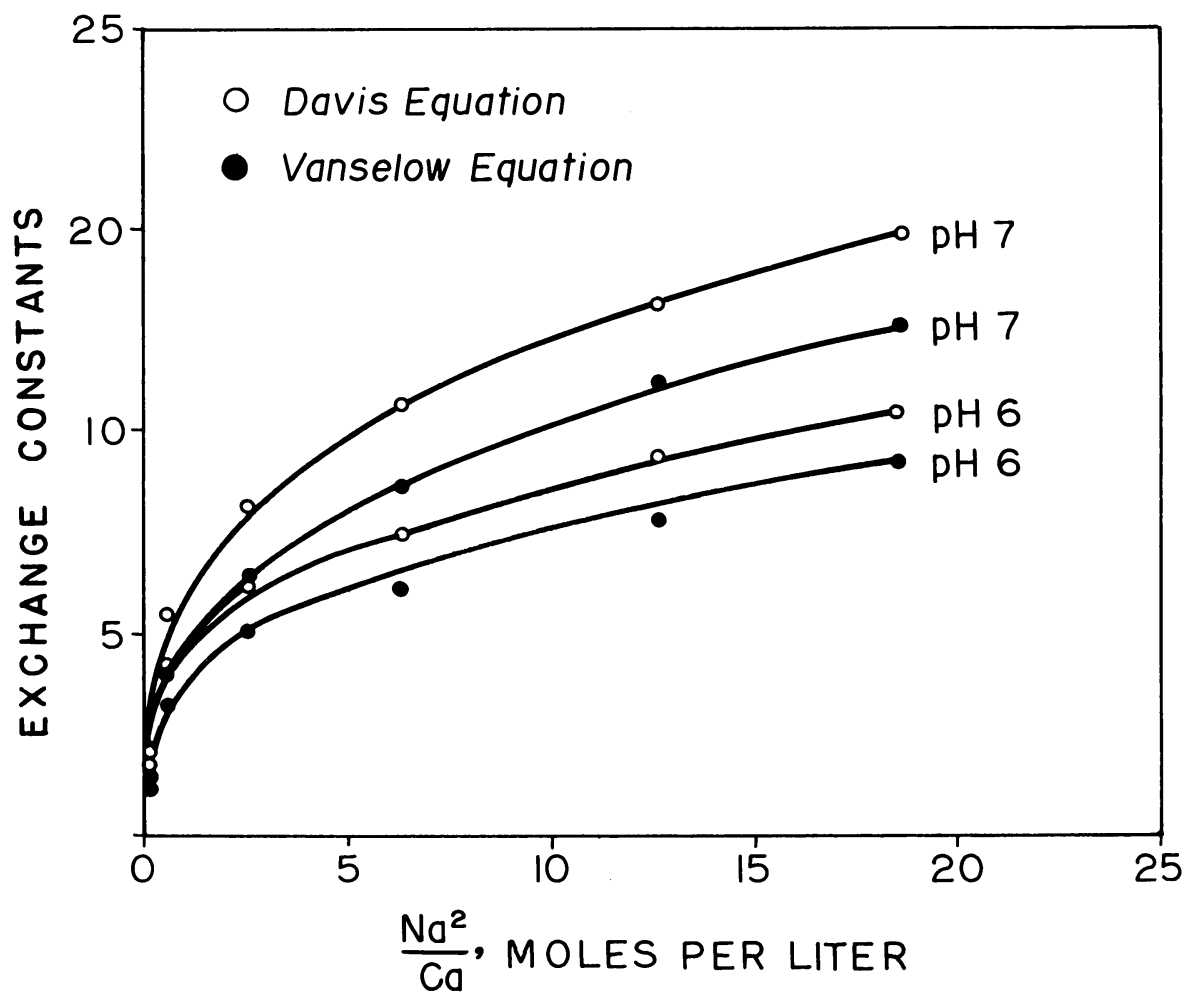

Fig. 7. Relations between the apparent exchange constant calculated from Vanselow's and Davis' equations and the solution phase concentration of $\mathrm{Na}$ and $\mathrm{Ca}$ at $\mathrm{pH}$ values of 6 and 7 for soil No. 12 .

given, may explain all of the variations in such specificity. On the other hand, the specificity of adsorption of $\mathrm{Ca}$ vs. Na might be related to the chemical nature of the negative charge on some of the exchangers in the soils, and not to the surface charge density. The underestimation of the surface charge density of the exchangers because of materials that contribute to surface area, but not to CEC, as well as the specific nature of the negative charges, not related to surface charge density, probably influence the value of the correction factors necessary to make the double-layer equation agree with the experimental data.

The data on soil 12 at $\mathrm{pH}$ values of 6 and 7 were used to calculate constants for the exchange equations of Vanselow (1932) and of Davis $(1950 a, 1950 b)$ 
as used by Krishnamoorthy and Overstreet (1950). The results are presented in figure 7. Obviously, the exchange reaction according to either of these equations does not give a constant. The $\mathrm{K}$ values vary with change in cation concentrations in solution and with change in $\mathrm{pH}$. This lack of a constant is in agreement with the statement by Krishnamoorthy and Overstreet (1950) that a constant cannot be obtained in a reaction when two or more exchange materials are involved.

Since most soils are mixtures of two or more exchange materials and since all equations similar to those of Vanselow (1932) and Davis (1950a, 1950b) do not apply to these mixtures, the double-layer equation developed by Eriksson (1955), which does show some agreement with data obtained on soils, would seem to be the more useful one to apply to soil systems.

\section{SUMMARY}

Data are presented on the soluble cations, exchangeable cations, cationexchange capacity, $\mathrm{pH}$-dependent cation-exchange capacity and $\mathrm{Na}-\mathrm{Ca}$ exchange equilibria of a number of acid soils of central and southern California.

About half of the soils collected were of medium to high salinity. About 20 per cent of the samples contained greater than $0.5 \mathrm{ppm} \mathrm{Al}$ in the saturation extract and about 40 per cent had greater than $10 \mathrm{ppm} \mathrm{Mn.} \mathrm{At} \mathrm{pH} \mathrm{values} \mathrm{of}$ 5 and above there was very little exchange acidity extracted by $N \mathrm{KCl}$ solution. Most of the acidity was $\mathrm{pH}$-dependent and was extracted by a $\mathrm{BaCl}_{2}$ solution buffered at $\mathrm{pH} 8.2$. At $\mathrm{pH}$ values below 5 some soils contained considerable exchange acidity which was largely accounted for by measuring exchangeable Al. For most soils the sum of the exchangeable cations, including the $\mathrm{pH}$-dependent acidity, was equal to the CEC measured by Ba adsorption at $\mathrm{pH} 8.0$.

All soils and clays contained a pH-dependent component of the CEC. The decrease in CEC with decrease in $\mathrm{pH}$ was found to be equal to the gain in $\mathrm{pH}$-dependent acidity. The contribution of organic matter to the $\mathrm{pH}$-dependent CEC was much greater than that of the clay. The CEC measured at the $\mathrm{pH}$ of the soil was a close estimate of the exchangeable cations plus exchange acidity extracted by $\mathrm{KCl}$ solution.

The ratio of adsorbed $\mathrm{Na}$ to adsorbed $\mathrm{Ca}$ increased with decrease in $\mathrm{pH}$; as the CEC decreased with reduction in $\mathrm{pH}$, the exchangeable $\mathrm{Ca}$ decreased more than exchangeable $\mathrm{Na}$. The relative change in the ratio of adsorbed $\mathrm{Na}$ to Ca was predicted by an exchange equation based on the Poisson-Boltzmann differential equation. For a good agreement between the exchange equation and the experimental data the surface charge density had to be multiplied by a factor which was specific for each soil. These factors varied from 1.0 to 2.1. 


\section{LITERATURE CITED}

BoLT, G. H.

1955. Ion adsorption by clays. Soil Sci. $79: 267-276$.

Bower, C. A.

1959. Cation-exchange equilibria in soils affected by sodium salts. Soil Sci. 88:32-35.

Bower, C. A., and J. O. Goertzen

1959. Surface area of soils and clays by an equilibrium ethylene glycol method. Soil Sci. $87: 289-292$.

Cole, R. C.

1949. Reaction of California soils. Calif. Agr. Expt. Sta. Bul. 712.

Coleman, N. T., S. B. Weed, and R. J. McCracken

1959. Cation-exchange capacity and exchangeable cations in Piedmont soils of North Carolina. Soil Sci. Soc. Amer. Proc. 23:146-149.

Davis, L. E.

1950a. Ionic exchange and statistical thermodynamics I. Equilibria in simple exchange systems. Jour. Colloid Sci. 5:71-79.

$1950 b$. Ionic exchange and statistical thermodynamics II. Equilibria in irregular systems. Jour. Colloid Sci. 5:107-113.

ERIKSSON, E.

1952. Cation-exchange equilibria on clay minerals. Soil Sci. $74: 103-113$.

Krishnamoorthy, C., and R. Overstreet

1950. An experimental evaluation of ion-exchange relationships. Soil Sci. 69:41-53.

Lunin, J., and A. R. BATCHELDER

1961. Cation exchange in acid soils upon treatment with saline solutions. Proc. Seventh Cong. Int. Soil Sci. Soc. 1:507-15.

Magistad, O. C.

1925. The aluminum content of the soil solution and its relation to soil reaction and plant growth. Soil Sci. $20: 181-225$.

McColloch, R. C., F. T. Bingham, and D. G. Aldrich

1957. Relation of soil potassium and magnesium to magnesium nutrition of citrus. Soil Sci. Soc. Amer. Proc. 21 :85-88.

Pierre, W. H., G. G. Pohlman, and T. C. McIlvaine

1932. Soluble aluminum studies: I. The concentration of aluminum in the displaced soil solution of naturally acid soils. Soil Sci. $34: 145-160$.

Pratt, P. F., Benoist Goulben, and R. B. Harding

1957. Changes in organic carbon and nitrogen in an irrigated soil during 28 years of differential fertilization. Soil Sci. Soc. Amer. Proc. 21 :215-219.

Pratt, P. F., and R. B. HARding

1957. Decreases in exchangeable magnesium in an irrigated soil during 28 years of differential fertilization. Agron. Jour. 49:419-421.

RusselL, E. W.

1950. Soil Conditions and Plant Growth. Eighth Edition, Longmans, Green and Co., New York.

Schmehl, W. R., M. Peech, and R. Bradfield

1950. Causes of poor growth of plants on acid soils and beneficial effects of liming: I. Evaluation of factors responsible for acid-soil injury. Soil Sci. 70:393-410.

SCHOFIELD, R. K.

1949. Effect of $\mathrm{pH}$ on electric charges carried by clay particles. Jour. Soil Sci. 1:1-8.

U. S. Salinity' Laboratory StafF

1954. Diagnosis and improvement of saline and alkali soils. U. S. Dept. Agr. Handbook No. 60.

VANSELOW, A. P.

1932. Equilibria of the base-exchange reactions of bentonites, permutites, soil colloids, and zeolites. Soil Sci. $33: 95-113$. 
The journal Hilgardia is published at irregular intervals, in volumes of about 600 pages. The number of issues per volume varies.

Subscriptions are not sold. The periodical is sent as published only to libraries, or to institutions in foreign countries having publications to offer in exchange.

You may obtain a single copy of any issue free, as long as the supply lasts; please request by volume and issue number from:
Agricultural Publications
Room 207 University Hall
University of California
Berkeley 4, California

The limit to nonresidents of California is 10 separate issues on a single order. A list of the issues still available will be sent on request. 